\title{
Sistem Identifikasi Plat Nomor Kendaraan Menggunakan Metode Robert Filter dan Framing Image Berbasis Pengolahan Citra Digital
}

\author{
Husnibes Muchtar ${ }^{1}$, Fachri Said ${ }^{2}$ \\ 1) 2) Teknik Elektro Universitas Muhammadiyah Jakarta \\ Jl. Cempaka Putih Tengah 27 No 47 \\ Email: ${ }^{1)}$ husnibes.muchtar@ftumj.ac.id, ${ }^{2)}$ 2014420003@ftumj.ac.id
}

\begin{abstract}
ABSTRAK
Kendaraan merupakan salah satu hal terpenting dalam kehidupan manusia. Kendaraan merupakan alat transportasi untuk bepergian kemanapun yang kita inginkan. Kendaraan juga menjadi sasaran penjahat untuk melakukan pencurian terhadap kendaraan tersebut, maupun menyalahgunakan kendaraan untuk berbuat kejahatan khususnya pada perumahan. Salah satu pemanfaatan teknologi untuk mengurangi hal tersebut, dengan sistem identifikasi plat nomor kendaraan menggunakan pengolahan citra digital. Dalam sistem identifikasi ini penulis menggunakan metode Robert filter dan framing image. Terdapat beberapa tahapan dalam sistem identifikasi ini yaitu pengambilan gambar, pemotongan, grayscale, pengambangan, Robert filter, framing image, dan pengenalan pola. Analisa kemampuan sistem identifikasi ini dilakukan pada beberapa tahap yaitu pengujian pada jarak horizontal dengan sudut $0^{\circ}$, pengujian jarak horizontal dengan sudut $10^{\circ}$, dan pengujian jarak vertikal dengan sudut $0^{\circ}$. Dari hasil pengujian diperoleh hasil penyimpangan rata rata terkecil dalam setiap tahap pengujiannya.
\end{abstract}

Kata Kunci : kendaraan, pengolahan citra digital, Robert filter, framing image

\section{PENDAHULUAN}

Saat ini, perkembangan dunia teknologi yang demikian mengagumkan itu telah membawa manfaat yang luar biasa bagi kemajuan peradaban umat manusia. Jenis-jenis pekerjaan yang sebelumnya menuntut kemampuan fisik yang cukup besar, kini relatif sudah bisa digantikan oleh perangkat mesinmesin otomatis, Demikian juga ditemukannya formulasi-formulasi baru kapasitas komputer, seolah sudah mampu menggeser posisi kemampuan otak manusia dalam berbagai bidang ilmu dan aktifitas manusia. Ringkas kata kemajuan teknologi yang telah kita capai sekarang benar-benar telah diakui dan dirasakan memberikan banyak kemudahan dan kenyamanan bagi kehidupan umat manusia. Namun manusia tidak bisa pula menipu diri sendiri akan kenyataan bahwa teknologi mendatangkan malapetaka dan kesengsaraan bagi manusia. Salah satu dampak negatif dari berkembangnya teknologi yaitu meningkatnya kriminalitas yang menggunakan teknologi. Hal ini membutuhkan suatu sistem keamanan yang memiliki tingkat efisien yang baik. Teknik pengolahan citra digital yang dikelompokkan dalam operasi titik, operasi global, operasi berbasis bingkai, operasi geometrik, dan operasi bertetangga [1]. Citra bisa berbentuk sebagai foto, atau sinyalsinyal vidio seperti gambar pada monitor televisi, atau bersifat digital yang dapat langsung disimpan langsung pada suatu media penyimpanan [2]. Delphi merupakan bahasa pemrograman sekaligus software development kit yang secara luas dapat dipakai untuk mebuat aplikasi [3]. Sistem pengenalan dan pembacaan plat nomor kendaraan digunakan dalam berbagai aplikasi seperti akses tempat parkir, pengendalian trafik lalu lintas dan sistem keamanan dan pengawasan kendaraan [4]. Pendeteksian nomor polisi kendaraan bermotor berbasis citra digital menggunakan metode binerisasi dan tempale matching [5]. Sistem identifikasi nomor kendaraan ecara otomasi memiliki peranan penting untuk mengtasi masalah perparkiran, memonitor kemacetan dan melacak kendaraan curian [6]. Tegangan sirkuit terbuka akan bertambah jika sel sel surya dihubungkan secara seri[7]. Kemajuan teknologi yang pada masa sekarang ini terus mengalami perkembangan dan di ikuti oleh sebagian bahkan hampir semua kalangan [8]. Didalam sistem jaringan distribusi listrik lokal (local grid) yang kita mengenal istilah microgrid dan nanogrid yang terkenal untuk pembangkit listrik yang berdiri sendiri [9]. Energi listrik merupakan salah satu kebutuhan pokok yang sangat penting dalam kehidupan manusia saat ini, hampir semua aktifitas manusia berhubungan dengan energi listrik [10]. Untuk dapat mendayai suatu beban listrik dengan baik, dalam hal ini merupakan rumah kaca, diperlukan desain sistem yang baik pula [11]. Pengukuran adalah suatu pembandingan antara suatu besaran dengan besaran lain yang sejenis secara eksperimen dan salah satu besaran dianggap sebagai standar [12]. Salah satu bahan semikonduktor organik yang sering digunakan adalah pentacene karena ketersediaannya dan kinerja divaisnya [13]. Energi 
menjadi salah satu isu yang dihadapi oleh Indonesia saat ini bahkan dunia, karena ketidakseimbangan antara ketersediaan energi dengan kebutuhanya [14]. Iradiasi surya biasanya diukur dengan solarimeter yang ditempatkan pada permukaan datar [15]. Penggunaan kapasitor bank di industri misalnya sebagai alat kompensator faktor daya, memperbaiki drop tegangan pada ujung jaringan, atau kenaikan suhu dan arus pada penghantar bisa diperkecil dengan di pasang kapasitor [16]. Transistor efek medan berbasis semikonduktor organik bisa dimanfaatkan untuk sensor kelembaban [17]. Sepeda motor merupakan kendaraan yang lazim digunakan oleh semua kalangan; mulai dari kalangan atas, menengah, sampai kalangan bawah [18]. Material organik telah menjadi perhatian para peneliti meskipun karakternya kurang dari silikon [19]. Perkembangan dibidang ilmu pengetahuan dan teknologi memiliki kemajuan yang sangat pesat yang berdampak pada kehidupan kita saat ini [20]. Teknik elektro merupakan salah satu dari ilmu teknik dasar yang merupakan komponen esensial dari perkembangan ilmu pengetahuan alam dan teknologi [21]. Rangkaian penyearah gelombang penuh adalah penyearah yang mengonversikan kedua siklus positif dan negative dari sinyal AC menjadi sinyal DC yang berdenyut [22]. Mengerjakan proyek tepat waktu sesuai dengan biaya, lingkup pekerjaan, serta mutu yang sudah ditetapkan menjadi target setiap perusahaan [23]. Sumber energi fosil seperti minyak bumi, gas alam dan batubara akan bisa bertahan jika sumber energi terbarukan digunakan [24]. Security home adalah sebuah rumah yang didesain untuk menjaga kemanan rumah melalui perangkat keras maupun perangkat lunak untuk memberikan keamanan dari segi pintu, system alarm, detector gerak (passive infrared), detector api, gas, maupun air [25]. Intensitas radiasi cahaya matahari yang diterima sel surya sebanding dengan tegangan dan arus listrik yang dihasilkan oleh sel surya [26]. Ada banyak sumber energi terbarukan seperti energi air, energi angin dan energi matahari [27]. Energi merupakan bagian yang paling penting bag makhluk hidup untuk bisa terus bertahan hidup [28]. Transistor film tipis organik memiliki potensi untuk penggunaan pada aplikasi elektronika yang biayanya rendah, permukaannya luas, ringan dan fleksibel [29]. PLTH ini dioperasikan untuk memikul beban [30]. Rangkaian band pass filter adalah rangkaian yang mengizinkan lewat sinyal yang memiliki frekuensi pada rentang tertentu dan mengattenuasikan sinyal yang memiliki frekuensi di luar rentang tersebut [31]. Perkembangan teknologi mendorong sektor industri untuk lebih kreatif dalam membuat sebuah alat sederhana yang dapat membantu masyarakat dalam kehidupan sehari-hari sehingga dapat berguna bagi banyak orang dan berfungsi baik [32]. Energi sangat penting untuk manusia untuk bisa bertahan hidup [33]. Operasi pembangkit tenaga listrik harus aman dan terpercaya [34]. Salah satu teknologi yang berkembang begitu pesat adalah pengolahan citra. Banyak peralatan elektro seperti scanner, kamera digital, mickrosop digital. Perangkat lunak untuk mengolah citra digital sangat populer dalam perkembangannya, digunakan oleh pengguna untuk mengolah foto atau untuk sebagai keperluan lain. Dengan demikian pengolahan citra sangat berperan penting diberbagai aspek selain mempermudah penggunanya juga dapat meningkatkan kinerja dalam tugas - tugas yang dikerjakan khususnya dalam pengolahan citra. Metode penyegmentasia dan pengenalan plat lisensi melingkupi penangkapan citra dan prapemrosesan citra [35].

\section{METODOLOGI}

- Flowchart Sistem

Perancangan dan perencanaan alat merupakan bagian yang terpenting dalam pembuatan alat yang akan dirancang dalam penelitian ini.

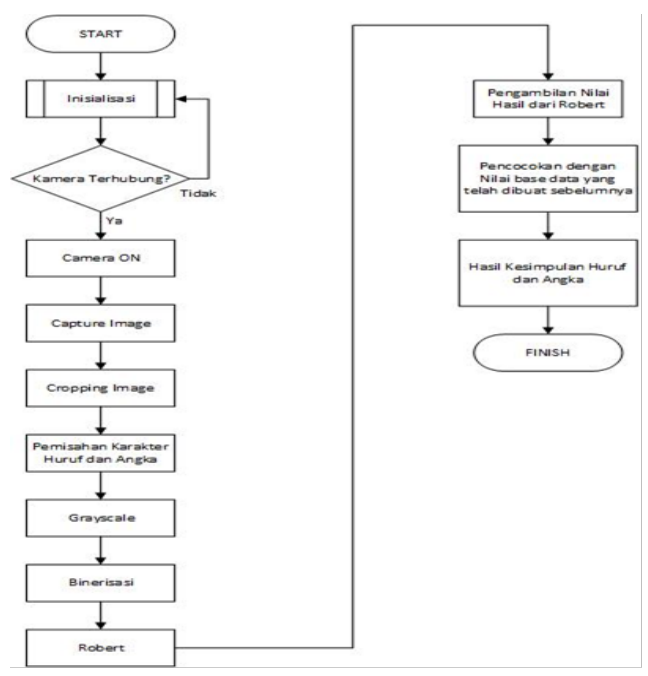

Gambar 1 Flowchart system.

Flowchart ini menunjukkan cara kerja dari sistem penelitian ini. Sistem ini dimulai ketika kita sudah memilih kamera apa yang akan digunakan. Setelah kamera terpilih, maka akan muncul tampilan gambar dari kamera tersebut. Tahap selanjutnya adalah pengambilan gambar kendaraan yang akan dideteksi. Setelah gambar didapat, maka selanjutnya adalah pemotongan gambar. Pemotongan gambar ini untuk mencari plat nomor yang akan di proses. Setelah itu, proses selanjutnya adalah pemisahan setiap huruf dan angka. Proses pemisahan ini dilakukan secara otomatis oleh sistem. Setelah didapat huruf dan angka yang 
RESISTOR (Elektronika Kendali Telekomunikasi Tenaga Listrik Komputer) Vol. 2 No. 2 e-ISSN : 2621-9700, p-ISSN : 2654-2684

terpisah ini, maka setiap gambar huruf dan angka yang terpisah tersebut mengalami proses grayscale. Setelah didapat hasil dari grayscale, barulah gambar diubah menjadi hitam dan putih (binerisasi). Setelah binerisasi, maka gambar diproses ke dalam Robert. Fungsi Robert ini adalah untuk mencari tepi pada gambar. $\mathrm{F}(\mathrm{x}, \mathrm{y})$ secara matematis serupa dengan $\mathrm{F}$ (baris, kolom) [36].

Didalam proses Robert ini, didapatkan nilai dari setiap gambar huruf dan angka. Nilai dari gambar huruf dan angka yang baru didapat ini akan mengalami proses pencocokan dari data nilai setiap huruf dan angka yang telah dibuat sebelumnya. Ketika data baru cocok dengan data base yang telah dibuat maka dapat diambil keputusan huruf dan angka apa yang terdapat dalam gambar yang baru diambil.

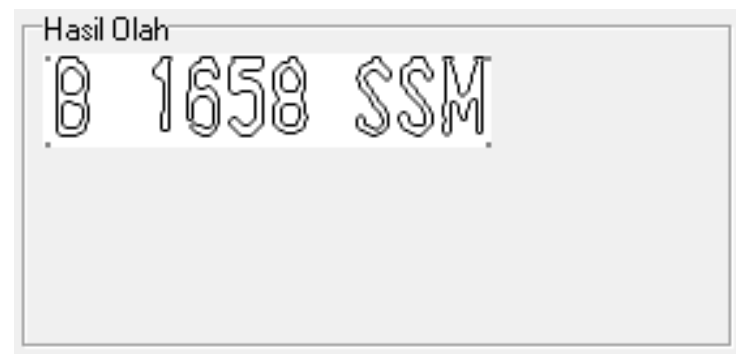

Gambar 2 Hasil robert filter.

- Metode Framming Image

Metode yang digunakan adalah dengan menscan warna hitam hasil gambar pada Robert secara vertikal, maka akan memunculkan nilai-nilai dimana terdapat warna hitam.

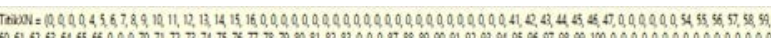

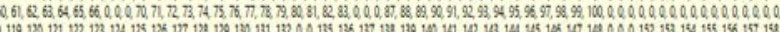

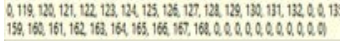

Gambar 3 Hasil scan vertikal gambar Robert.

Dari hasil scan vertikal pada Gambar 3 diatas, maka didapatkan lokasi titik-titik (x) mana saja yang terdapat warna hitamnya (Lokasi huruf dan angka) dan nilai (0) adalah nilai dimana terdapat warna putih pada gambar.

- Metode Pembuatan Database

Metode pembuatan database untuk huruf dan angka berdasarkan hasil pembacaan nilai Robert setelah di Framing.

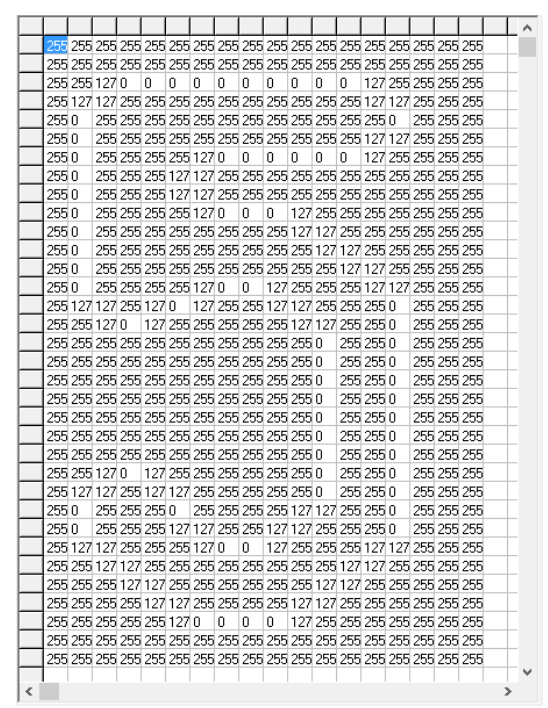

Gambar 4 Hasil pembacaan Robert setelah di framing.

Setelah didapat hasil pada Gambar 4, selanjutnya adalah menghitung ada berapa nilai 0 (hitam) dan nilai 255 (putih) yang terdapat pada huruf atau angka tersebut (nilai 127 pada gambar termasuk kedalam warna hitam, jadi dikategorikan kedalam nilai 0). Hasil perhitungan itulah yang dijadikan basedata untuk huruf atau angka tersebut.

\section{HASIL DAN PEMBAHASAN}

Pengujian Sistem Identifikasi Plat Nomor Kendaraan dengan metode Robert filter ini dilakukan tiga tahap yaitu pengujian jarak horizontal dengan sudut $0^{\circ}$, pengujian jarak horizontal dengan sudut $10^{\circ}$, dan pengujian jarak vertikal dengan sudut $10^{\circ}$. Pengujian selanjutnya akan dilakukan perbandingan terhadap data base yang telah dibuat pada Tabel 1 .

Tabel 1 Data base huruf dan angka.

\begin{tabular}{|c|c|c|c|c|c|c|}
\hline \multicolumn{6}{|c|}{ Database Sample Plat Nomor (satuan piksel) } \\
\hline B & 1 & 6 & 5 & 8 & S & M \\
\hline 164 & 74 & 160 & 138 & 164 & 146 & 176 \\
\hline
\end{tabular}
persamaan sebagai berikut:

Penyimpangan $(\%)=\left|\frac{P_{r a}-P_{d b}}{P_{d b}}\right| \times 100 \%$

dimana :

$P_{r a}=$ Data piksel rata-rata

$P_{d b}=$ Data piksel database

Pengujian jarak horizontal dengan sudut $0^{\circ}$ dilakukan dengan tiga percobaan jarak yaitu pada jarak $100 \mathrm{~cm}, 105 \mathrm{~cm}$, dan $110 \mathrm{~cm}$. Hasil pengujian diperlihatkan pada Tabel 2 dibawah ini. 
RESISTOR (Elektronika Kendali Telekomunikasi Tenaga Listrik Komputer) Vol. 2 No. 2 e-ISSN : 2621-9700, p-ISSN : 2654-2684

Tabel 2 Data pengujian jarak $100 \mathrm{~cm}$ sudut $0^{\circ}$ horizontal.

\begin{tabular}{|c|c|c|c|c|c|c|c|c|}
\hline \multirow{2}{*}{ Percobaan ke- } & \multicolumn{7}{|c|}{ Sarak $100 \mathrm{~cm}$ sudut $0^{\circ}$} \\
\cline { 2 - 9 } & $\mathrm{B}$ & 1 & 6 & 5 & 8 & $\mathrm{~S}$ & $\mathrm{~S}$ & $\mathrm{M}$ \\
\hline & 164 & 74 & 158 & 138 & 166 & 146 & 146 & 174 \\
\hline 1 & 164 & 74 & 158 & 138 & 164 & 146 & 146 & 176 \\
\hline 2 & 164 & 74 & 160 & 138 & 162 & 146 & 146 & 174 \\
\hline 3 & 164 & 74 & 160 & 138 & 162 & 146 & 146 & 174 \\
\hline 4 & 164 & 74 & 160 & 138 & 164 & 146 & 146 & 174 \\
\hline 5 & 164 & 74 & 159.2 & 138 & 163.6 & 146 & 146 & 174.4 \\
\hline & 0 & 0 & 0.5 & 0 & 0.244 & 0 & 0 & 0.909 \\
\hline Rata-rata & 16 & & & & & & \\
\hline $\begin{array}{c}\text { Penyimpangan } \\
\text { (\%) }\end{array}$ & 0 & &
\end{tabular}

Dari hasil data penyimpangan setiap huruf dan angka pada pengujian jarak $100 \mathrm{~cm}$ dengan sudut $0^{\circ}$ dapat dilihat penyimpangan yang terjadi tidak terlalu besar yaitu mulai dari 0\% sampai $0.909 \%$. Hal ini menyebabkan dapat terbacanya semua huruf dan angka pada plat nomor, penyimpangan rata-rata yang terjadi, yaitu sebesar $0.21 \%$.

(Q) ब $\begin{array}{lllllll}164 & 74 & 160 & 138 & 164 & 146146 & 174\end{array}$ 448538452474448466466438

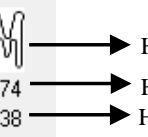
Hasil Framming

Hasil Perhitungan nilai 0 (hitam) Hasil Perhitungan nilai 255 (putih)

Gambar 5 Hasil framming dan hasil perhitungan nilai piksel pada jarak $100 \mathrm{~cm}$ dengan sudut $0^{\circ}$ horizontal.

Tabel 3 Data pengujian jarak $105 \mathrm{~cm}$ sudut $0^{\circ}$ horizontal.

\begin{tabular}{|c|c|c|c|c|c|c|c|c|}
\hline \multirow{2}{*}{ Percobaan ke- } & \multicolumn{7}{|c|}{ Jarak $105 \mathrm{~cm}$ sudut $0^{\circ}$} \\
\cline { 2 - 9 } & $\mathrm{B}$ & 1 & 6 & 5 & 8 & $\mathrm{~S}$ & $\mathrm{~S}$ & $\mathrm{M}$ \\
\hline 1 & 158 & 70 & 148 & 136 & 152 & 140 & 142 & 170 \\
\hline 2 & 158 & 70 & 148 & 136 & 152 & 140 & 142 & 170 \\
\hline 3 & 158 & 70 & 150 & 138 & 154 & 138 & 142 & 174 \\
\hline 4 & 158 & 70 & 150 & 138 & 154 & 138 & 142 & 174 \\
\hline 5 & 158 & 70 & 150 & 138 & 154 & 140 & 142 & 172 \\
\hline & \multicolumn{8}{|c|}{$|c| c|c| c \mid$} \\
\hline Rata-rata & 158 & 70 & 149.2 & 137.2 & 153.2 & 139.2 & 142 & 172 \\
\hline $\begin{array}{c}\text { Penyimpangan } \\
\text { (\%) }\end{array}$ & 3.659 & 5.405 & 6.75 & 0.579 & 6.585 & 4.658 & 2.739 & 2.273 \\
\hline
\end{tabular}

Pada Tabel 3 menunjukan hasil dari pengujian pada jarak $105 \mathrm{~cm}$ dengan sudut $0^{\circ}$, berdasarkan perbandingan hasil rata-rata pengujian dengan database terjadi penyimpangan mulai dari yang terkecil yaitu $0.579 \%$ sampai yang terbesar yaitu $6.75 \%$. Hal ini menyebabkan tidak dapat terbacanya beberapa huruf dan angka yaitu huruf B, S, M dan angka 1,6 , dan 8 . Penyimpangan rata-rata yang terjadi pada Tabel 3 yaitu sebesar $4.08 \%$.

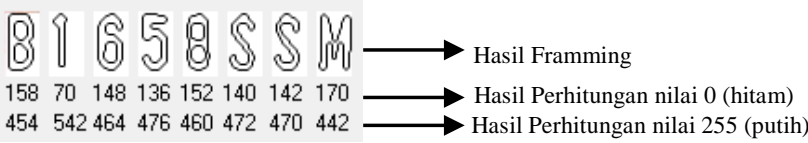

Gambar 6 Hasil framming dan hasil perhitungan nilai piksel pada jarak $105 \mathrm{~cm}$ dengan sudut $0^{\circ}$ horizontal.

Tabel 4 Data pengujian jarak $110 \mathrm{~cm}$ sudut $0^{\circ}$ horizontal.

\begin{tabular}{|c|c|c|c|c|c|c|c|c|}
\hline \multirow{3}{*}{ Percobaan ke- } & \multicolumn{8}{|c|}{ Jarak $110 \mathrm{~cm}$ sudut $0^{\circ}$} \\
\hline & \multicolumn{8}{|c|}{ Sample Plat Nomor (satuan piksel) } \\
\hline & $\mathrm{B}$ & 1 & 6 & 5 & 8 & $\mathrm{~S}$ & $\mathrm{~S}$ & $\mathrm{M}$ \\
\hline 1 & 146 & 66 & 144 & 122 & 148 & 130 & 132 & 152 \\
\hline 2 & 146 & 66 & 146 & 126 & 150 & 132 & 134 & 154 \\
\hline 3 & 146 & 66 & 146 & 126 & 150 & 132 & 132 & 154 \\
\hline 4 & 146 & 66 & 146 & 126 & 150 & 132 & 132 & 154 \\
\hline 5 & 146 & 66 & 146 & 126 & 150 & 132 & 134 & 154 \\
\hline Rata-rata & 146 & 66 & 145.6 & 125.2 & 149.6 & 131.6 & 132.8 & 153.6 \\
\hline \begin{tabular}{|c|} 
Penyimpangan \\
$(\%)$
\end{tabular} & 10.976 & 10.811 & 9 & 9.275 & 8.7805 & 9.863 & 9.0411 & 12.727 \\
\hline
\end{tabular}

Pada Tabel 4 menunjukan hasil dari pengujian pada jarak $110 \mathrm{~cm}$ dengan sudut $0^{\circ}$, berdasarkan perbandingan hasil rata-rata pengujian dengan database terjadi penyimpangan mulai dari yang terkecil yaitu $8.780 \%$ sampai yang terbesar yaitu $12.727 \%$. Hal ini menyebabkan tidak dapat terbacanya semua huruf dan angka pada plat nomor. Penyimpangan rata-rata yang terjadi pada Tabel 4 yaitu sebesar $10.06 \%$.

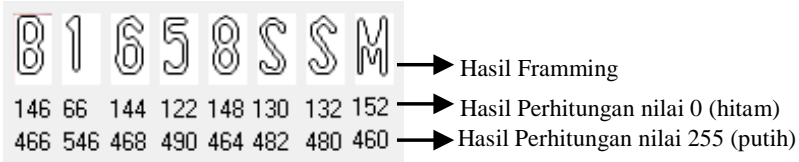

Gambar 7 Hasil framming dan hasil perhitungan nilai piksel pada jarak $110 \mathrm{~cm}$ dengan sudut $0^{\circ}$ horizontal.

Tabel 5 Data Pengujian jarak $100 \mathrm{~cm}$ sudut $10^{\circ}$ horizontal.

\begin{tabular}{|c|c|c|c|c|c|c|c|c|}
\hline \multirow{3}{*}{ Percobaan ke- } & \multicolumn{8}{|c|}{ Jarak $100 \mathrm{~cm}$ sudut $10^{\circ}$} \\
\hline & \multicolumn{8}{|c|}{ Sample Plat Nomor (satuan piksel) } \\
\hline & $\mathrm{B}$ & 1 & 6 & 5 & 8 & $\mathrm{~S}$ & $\mathrm{~S}$ & $\mathrm{M}$ \\
\hline 1 & 152 & 72 & 150 & 142 & 154 & 144 & 144 & 174 \\
\hline 2 & 154 & 72 & 148 & 144 & 154 & 146 & 144 & 170 \\
\hline 3 & 154 & 72 & 148 & 144 & 154 & 146 & 144 & 170 \\
\hline 4 & 152 & 72 & 148 & 144 & 154 & 146 & 144 & 170 \\
\hline 5 & 154 & 72 & 150 & 142 & 154 & 146 & 146 & 172 \\
\hline Rata-rata & 153.2 & 72 & 148.8 & 143.2 & 154 & 145.6 & 144.4 & 171.2 \\
\hline $\begin{array}{c}\text { Penyimpangan } \\
(\%)\end{array}$ & 6.585 & 2.703 & 7 & 3.768 & 6.098 & 0.274 & 1.096 & 2.727 \\
\hline
\end{tabular}

Pada Tabel 5 menunjukan hasil dari pengujian pada jarak $100 \mathrm{~cm}$ dengan sudut $10^{\circ}$, berdasarkan perbandingan hasil rata-rata pengujian dengan database terjadi penyimpangan mulai dari yang terkecil yaitu $0.274 \%$ sampai yang terbesar yaitu $6.585 \%$. Hal ini menyebabkan tidak dapat terbacanya semua angka dan beberapa huruf yaitu huruf B dan M. Penyimpangan rata-rata yang terjadi pada Tabel 5 yaitu sebesar $3.78 \%$. 
RESISTOR (Elektronika Kendali Telekomunikasi Tenaga Listrik Komputer) Vol. 2 No. 2 e-ISSN : 2621-9700, p-ISSN : 2654-2684

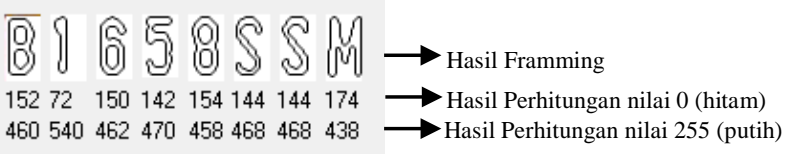

Gambar 8 Hasil framming dan hasil perhitungan nilai piksel pada jarak $100 \mathrm{~cm}$ dengan sudut $10^{\circ}$ horizontal.

Tabel 6 Data pengujian jarak $105 \mathrm{~cm}$ sudut $10^{\circ}$ horizontal.

\begin{tabular}{|c|c|c|c|c|c|c|c|c|}
\hline \multirow{2}{*}{ Percobaan ke- } & \multicolumn{7}{|c|}{ Jarak 105cm sudut $10^{\circ}$} \\
\cline { 2 - 9 } & $\mathrm{B}$ & 1 & 6 & 5 & 8 & $\mathrm{~S}$ & $\mathrm{~S}$ & $\mathrm{M}$ \\
\hline & 144 & 64 & 142 & 128 & 152 & 140 & 142 & 166 \\
\hline 1 & 142 & 64 & 142 & 128 & 152 & 140 & 142 & 164 \\
\hline 2 & 144 & 64 & 140 & 128 & 150 & 140 & 140 & 164 \\
\hline 3 & 144 & 64 & 140 & 130 & 152 & 140 & 142 & 164 \\
\hline 4 & 142 & 64 & 140 & 130 & 150 & 140 & 142 & 164 \\
\hline 5 & \multicolumn{10}{|c|}{} & & & & & & \\
\hline Rata-rata & 143.2 & 64 & 140.8 & 128.8 & 151.2 & 140 & 141.6 & 164.4 \\
\hline $\begin{array}{c}\text { Penyimpangan } \\
\text { (\%) }\end{array}$ & 12.683 & 13.514 & 12 & 6.6667 & 7.8049 & 4.1096 & 3.0137 & 6.5909 \\
\hline
\end{tabular}

Pada Tabel 6 menunjukan hasil dari pengujian pada jarak $105 \mathrm{~cm}$ dengan sudut $10^{\circ}$, berdasarkan perbandingan hasil rata-rata pengujian dengan database terjadi penyimpangan mulai dari yang terkecil yaitu 3.014\% sampai yang terbesar yaitu 13.514\%. Hal ini menyebabkan tidak dapat terbacanya semua huruf dan angka pada plat nomor. Penyimpangan rata-rata yang terjadi pada Tabel 6 yaitu sebesar $8.3 \%$.

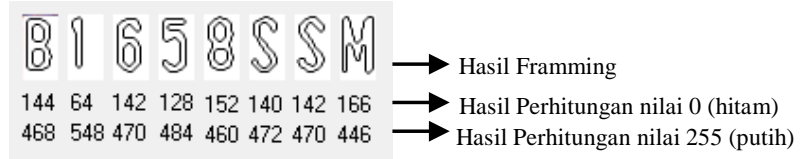

Gambar 9 Hasil framming dan hasil perhitungan nilai piksel pada jarak $105 \mathrm{~cm}$ dengan sudut $10^{\circ}$ horizontal.

Tabel 7 Data pengujian jarak $100 \mathrm{~cm}$ sudut $10^{\circ}$ vertikal.

\begin{tabular}{|c|c|c|c|c|c|c|c|c|}
\hline \multirow{3}{*}{ Percobaan ke- } & \multicolumn{8}{|c|}{ Jarak $100 \mathrm{~cm}$ sudut $10^{\circ}$} \\
\hline & \multicolumn{8}{|c|}{ Sample Plat Nomor (satuan piksel) } \\
\hline & $\mathrm{B}$ & 1 & 6 & 5 & 8 & $\mathrm{~S}$ & $\mathrm{~S}$ & $\mathrm{M}$ \\
\hline 1 & 158 & 72 & 154 & 136 & 156 & 136 & 134 & 166 \\
\hline 2 & 160 & 72 & 154 & 134 & 154 & 138 & 136 & 162 \\
\hline 3 & 160 & 72 & 154 & 136 & 156 & 138 & 136 & 164 \\
\hline 4 & 160 & 72 & 152 & 136 & 154 & 138 & 136 & 160 \\
\hline 5 & 160 & 72 & 152 & 136 & 154 & 138 & 136 & 162 \\
\hline Rata-rata & 159.6 & 72 & 153.2 & 135.6 & 154.8 & 137.6 & 135.6 & 162.8 \\
\hline $\begin{array}{c}\text { Penyimpangan } \\
\text { (\%) }\end{array}$ & 2.6829 & 2.7027 & 4.25 & 1.7391 & 5.6098 & 5.7534 & 7.1233 & 7.5 \\
\hline
\end{tabular}

Pada Tabel 7 menunjukan hasil dari pengujian pada jarak $100 \mathrm{~cm}$ dengan sudut $10^{\circ}$ vertikal, berdasarkan perbandingan hasil rata-rata pengujian dengan database terjadi penyimpangan mulai dari yang terkecil yaitu $1.739 \%$ sampai yang terbesar yaitu 7.123\%. Hal ini menyebabkan tidak dapat terbacanya semua huruf dan beberapa angka yaitu angka 1, 6, dan 8. Penyimpangan rata-rata yang terjadi pada Tabel 7 yaitu sebesar $4.67 \%$.

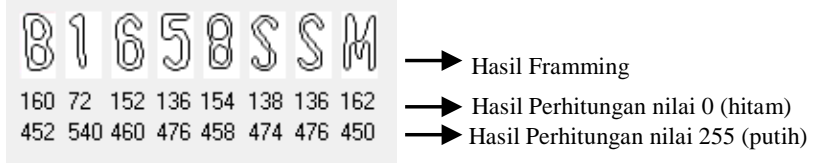

Gambar 10 Hasil framming dan hasil perhitungan nilai piksel pada jarak $100 \mathrm{~cm}$ dengan sudut $10^{\circ}$ vertikal.

Pada penelitian ini juga dilakukan percobaan pengujian pada plat nomor terbaru yang akan diterapkan oleh Pemerintah yaitu plat nomor dengan warna dasar putih dan warna hitam hitam dibagian tulisannya.

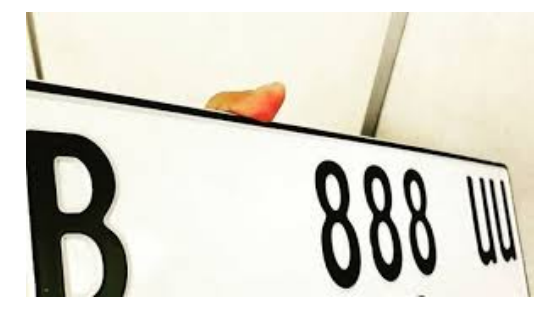

Gambar 11 Contoh plat nomor terbaru.

Dari hasil pengujian pada proses cropping atau pemotongan gambar terlihat jelas terdapat garis bantu yang masih terlihat pada hasil pemotongan.

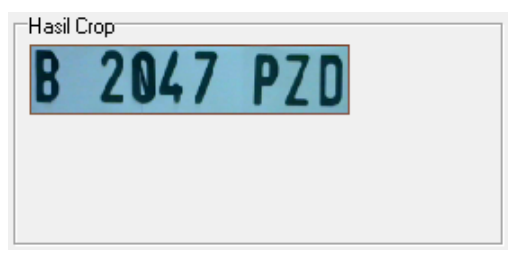

Gambar 12 Hasil pemotongan.

Pada pengolahan metode Robert filter, hasil gambar huruf dan angka yang diperoleh sukses menghasilkan hasil yang sama dengan pengujian pada plat nomor yang berwarna dasar hitam, tetapi garis tepi pada gambar masih terlihat.

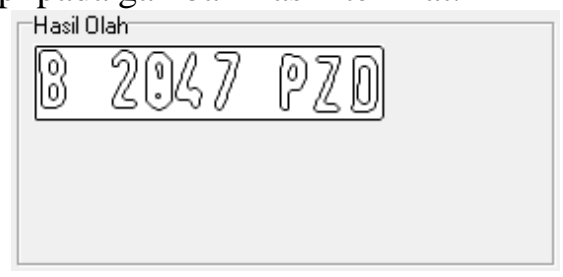

Gambar 13 Hasil robert filter pada plat nomor terbaru. 
RESISTOR (Elektronika Kendali Telekomunikasi Tenaga Listrik Komputer) Vol. 2 No. 2 e-ISSN : 2621-9700, p-ISSN : 2654-2684

Efek dari garis tepi yang masih terlihat pada gambar, sangat berpengaruh pada hasil Framing Image dan juga hasil pembacaan. Pada Gambar 14 terlihat jelas bahwa garis tepi juga masih terdapat pada proses framing, hal ini menyebabkan hasil pembacaan tidak hanya pada huruf atau angkanya saja tetapi tepi yang ikut pada proses framing juga ikut terhitung. Hal ini menyebabkan tidak dapat terbacanya huruf dan angka pada plat nomor karena penambahan nilai pembacaan pada tepi yang tidak diperlukan.

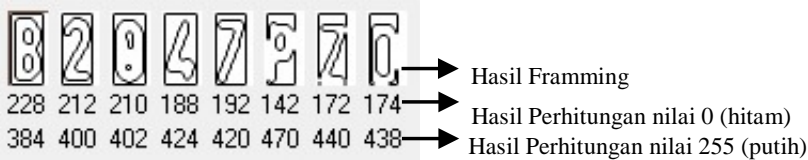

Gambar 14 Hasil framing dan hasil pembacaan pada plat nomor terbaru.

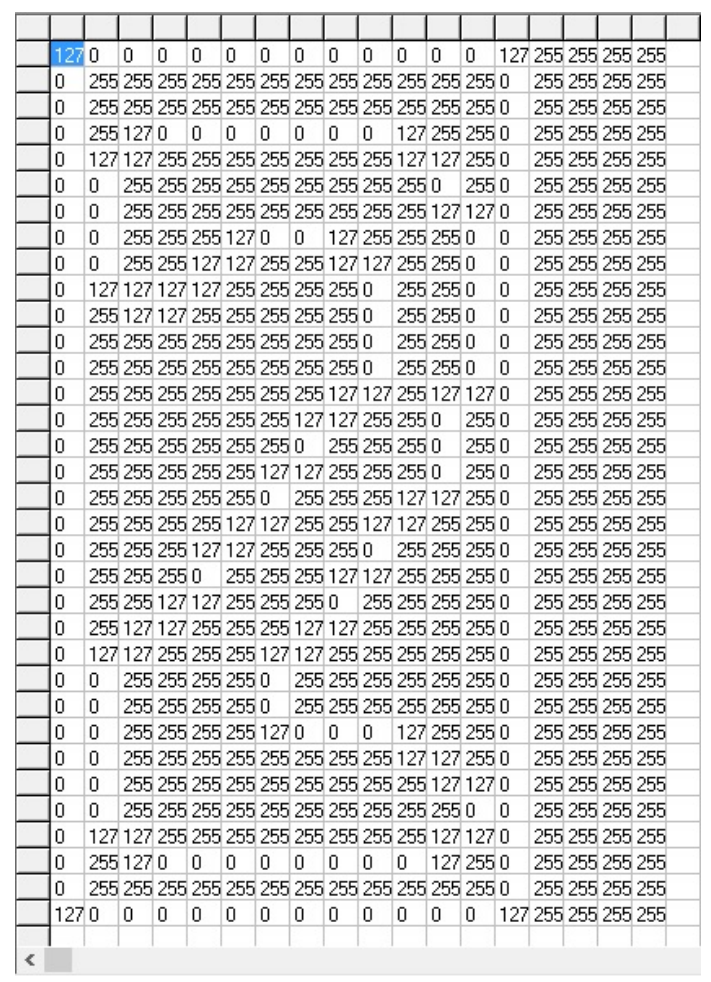

Gambar 15 Hasil pembacaan Robert filter pada plat nomor terbaru.

\section{KESIMPULAN}

Berdasarkan hasil penelitian, maka dapat ditarik kesimpulan yaitu:

- Pengujian pada jarak $100 \mathrm{~cm}$ dengan sudut $0^{\circ}$ horizontal memiliki nilai penyimpangan rata-rata yang paling kecil, yaitu sebesar $0.21 \%$ sehingga pembacaan pada sample plat nomor dapat terbaca dengan maksimal.

- Penurunan nilai piksel pada pengujian dapat disebabkan oleh beberapa faktor, yaitu sudut pengambilan gambar dan juga kondisi huruf atau plat nomor yang akan diproses.

- Metode Framming Image yang digunakan berhasil pada jarak $100 \mathrm{~cm}$ sampai $110 \mathrm{~cm}$.

- Dikarenakan metode Robert Filter menghasilkan tepi yang paling tipis, oleh sebab itu kondisi huruf dan angka pada plat nomor sangat berpengaruh pada hasil pembacaan.

- Sistem masih belum bisa digunakan pada pembacaan plat nomor terbaru yakni plat nomor dengan warna dasar putih dan warna hitam pada bagian tulisan.

\section{DAFTAR PUSTAKA}

[1] B. Achmad and K. Firdausy, Pengolahan Citra Digital Menggunakan Delphi. Penerbit Andi, 2013.

[2] P. N. Andono and T. Sutojo, Pengolahan Citra Digital. Penerbit Andi, 2017.

[3] J. Enterprise, Pemrograman Delphi untuk Pemula. Elex Media Komputindo, 2017.

[4] H. Fitriawan, O. Pucu, and Y. Baptista, "Identifikasi Plat Nomor Kendaraan Secara Off-Line Berbasis Pengolahan Citra dan Jaringan Syaraf Tiruan,” Electrician, vol. 6, no. 2, pp. 123-126, 2012.

[5] F. Yusuf, "Pendeteksian Nomor Polisi Kendaraan Bermotor Berbasis Citra Digital Menggunakan Metode Binerisasi Dan Tempale Matching," TEKNOSAINS: MEDIA INFORMASI SAINS DAN TEKNOLOGI, vol. 11, no. 1, 2017.

[6] A. Puranic, K. T. Deepak, and V. Umadevi, "Vehicle number plate recognition system: a literature review and implementation using template matching," International Journal of Computer Applications, vol. 134, no. 1, pp. 1216, 2016.

[7] H. Isyanto, F. Fadliondi, and B. Budiyanto, "STUDI SIMULASI DAN EKSPERIMEN PADA KARAKTERISTIK LISTRIK SEL SURYA YANG TERHUBUNG SECARA SERI,” Prosiding Semnastek, 2018.

[8] H. Isyanto and D. Arsito, "Sistem Pengaman Rumah dan Peringatan Dini Kebakaran Berbasis SMS dengan Menggunakan Raspberry Pi,” RESISTOR (elektRonika $k$ Endali telekomunikaSI tenaga liSTrik kOmputeR), vol. 1, no. 1, pp. 13-24, 2018. 
RESISTOR (Elektronika Kendali Telekomunikasi Tenaga Listrik Komputer) Vol. 2 No. 2 e-ISSN : 2621-9700, p-ISSN : 2654-2684

[9] S. Sriyono and B. Budiyanto, "Studi Penggunaan DC Nanogrid dengan Sumber Photovoltaic pada Beban Bertegangan dibawah Dua Puluh Empat Volt,” RESISTOR (elektRonika kEndali telekomunikaSI tenaga liSTrik kOmputeR), vol. 2, no. 1, pp. 1-6, 2019.

[10] R. Samsinar and W. Wiyono, "Studi Keandalan Rekonfigurasi Jaringan Program Zero Down Time (Zdt) di Kawasan Sudirman Central Business Distric (Scbd) Menggunakan Software ETAP 12.6,” RESISTOR (elektRonika kEndali telekomunikaSI tenaga liSTrik kOmputeR), vol. 2, no. 1, pp. 65-72, 2019.

[11] L. Halim and C. F. Naa, "Desain Sistem Pendayaan Energi Listrik pada Rumah Kaca Pintar dengan Menggunakan Pembangkit Listrik Tenaga Surya,” RESISTOR (elektRonika kEndali telekomunikaSI tenaga liSTrik kOmputeR), vol. 2, no. 1, pp. 43-50, 2019.

[12] D. Almanda and B. Kusuma, "Audit Energi Listrik Pabrik,” RESISTOR (elektRonika kEndali telekomunikaSI tenaga liSTrik kOmputeR), vol. 1, no. 1, 2018.

[13] F. Fadliondi, M. Kunta Biddinika, and S. I. Omi, "The Humidity Dependence of Pentacene Organic Metal-Oxide-Semiconductor FieldEffect Transistor.," Telkomnika, vol. 15, no. 2, 2017.

[14] P. G. Chamdareno, E. Nuryanto, and E. Dermawan, "Perencanaan Sistem Pembangkit Listrik Hybrid (Panel Surya dan Diesel Generator) pada Kapal KM. Kelud,” RESISTOR (elektRonika kEndali telekomunikaSI tenaga liSTrik kOmputeR), vol. 2, no. 1, pp. 59-64, 2019.

[15] P. G. Chamdareno, B. Budiyanto, F. Fadliondi, and H. Isyanto, "STUDI EKSPERIMEN TERHADAP PANEL SURYA DAN INVERTER,” Prosiding Semnastek, 2017.

[16] D. Almanda and N. Majid, "Studi Analisa Penyebab Kerusakan Kapasitor Bank Sub Station Welding di PT. Astra Daihatsu Motor,” RESISTOR (elektRonika kEndali telekomunikaSI tenaga liSTrik kOmputeR), vol. 2, no. 1, pp. 7-14, 2019.

[17] F. Fadliondi and B. Budiyanto, "Transistor Efek Medan Berbasis Semikonduktor Organik Pentacene untuk Sensor Kelembaban,” Jurnal Nasional Teknik Elektro dan Teknologi Informasi, vol. 6, no. 2, pp. 204-209, 2017.
[18] H. Isyanto, A. Solikhin, and W. Ibrahim, "Perancangan dan Implementasi Security System pada Sepeda Motor Menggunakan RFID Sensor Berbasis Raspberry Pi," RESISTOR (elektRonika kEndali telekomunikaSI tenaga liSTrik kOmputeR), vol. 2, no. 1, pp. 29-38, 2019.

[19] F. Fadliondi, H. Isyanto, and P. G. Chamdareno, "The comparison of organic field effect transistor (OFET) structures,” in 2017 2nd International Conference on Frontiers of Sensors Technologies (ICFST), 2017, pp. 6-9.

[20] M. H. Widianto, “Alat Pengatur Suhu Otomatis pada Ruangan Produksi Textile Spining Berbasis Mikrokontroler Atmega32 di PT. San Star Manunggal," RESISTOR (elektRonika kEndali telekomunikaSI tenaga liSTrik kOmputeR), vol. 2, no. 1, pp. 51-58, 2019.

[21] F. Fadliondi, P. G. Chamdareno, and H. Isyanto, "Perbandingan Pemahaman tentang Instalasi Listrik Rumah Tinggal antara Sebelum dan Sesudah Mengikuti Pelatihan,” Jurnal Pengabdian Masyarakat Teknik, vol. 1, no. 1, pp. 1-11, 2018.

[22] F. Fadliondi, N. Hasanah, and A. Asriyadi, "Simulasi dan Pembuatan Rangkaian Penyearah Gelombang Penuh dengan Trafo Center Tapped dengan Memakai Perangkat Lunak LT SPICE,” RESISTOR (elektRonika kEndali telekomunikaSI tenaga liSTrik kOmputeR), vol. 2, no. 1, pp. 23-28, 2019.

[23] E. B. Prasetya, “Aplikasi Manajemen Proyek Konstruksi dengan Metode Critical Path dan Earned Value Management,” RESISTOR (elektRonika kEndali telekomunikaSI tenaga liSTrik kOmputeR), vol. 1, no. 2, pp. 53-68, 2018.

[24] F. Fadliondi, H. Isyanto, and B. Budiyanto, "Bypass Diodes for Improving Solar Panel Performance," International Journal of Electrical and Computer Engineering, vol. 8, no. 5, p. 2703, 2018.

[25] H. Isyanto and M. Syahrullah, "Perancangan Security Home (Keamanan pada Rumah) Menggunakan Mikrokontroller Berbasis SMS (Short Message Service)," RESISTOR (elektRonika kEndali telekomunikaSI tenaga liSTrik kOmputeR), vol. 1, no. 2, pp. 85-96, 2018.

[26] D. Almanda and D. Bhaskara, "Studi Pemilihan Sistem Pendingin pada Panel Surya 
RESISTOR (Elektronika Kendali Telekomunikasi Tenaga Listrik Komputer) Vol. 2 No. 2 e-ISSN : 2621-9700, p-ISSN : 2654-2684

Menggunakan Water Cooler, Air Mineral dan Air Laut,” RESISTOR (elektRonika kEndali telekomunikaSI tenaga liSTrik kOmputeR), vol. 1, no. 2, pp. 43-52, 2018.

[27] F. Fadliondi, B. Budiyanto, and H. Isyanto, "SIMULASI KARAKTERISTIK LISTRIK DARI SEL SURYA YANG TERHUBUNG SECARA PARALEL DAN PENGUJIANNYA SECARA EKSPERIMEN,” Prosiding Semnastek, 2018.

[28] H. Isyanto, B. Budiyanto, F. Fadliondi, and P. G. Chamdareno, "Pendingin Untuk Peningkatan Daya Keluaran Panel Surya," Prosiding Semnastek, 2017.

[29] F. Fadliondi, H. Isyanto, and P. Gagani, "Pengaruh Ketebalan Lapisan Isolator Sio2 terhadap Mobilitas Lubang dari Transistor Efek Medan Organik Pentacene,” Prosiding Semnastek, 2016.

[30] P. G. Chamdareno and H. Hilal, "Analisa Pembangkit Listrik Tenaga Hybrid PLTDPLTS di Pulau Tunda Serang Banten,” RESISTOR (elektRonika kEndali telekomunikaSI tenaga liSTrik kOmputeR), vol. 1, no. 1, pp. 35-42, 2018.

[31] F. Fadliondi and A. Asriyadi, "Eksperimen dan Simulasi Rangkaian Band Pass Filter (BPF) dengan Resistor dan Kapasitor," RESISTOR (elektRonika kEndali telekomunikaSI tenaga liSTrik kOmputeR), vol. 1, no. 2, pp. 69-78, 2018.

[32] M. H. Widianto, "Pengaplikasian Sensor Hujan dan LDR untuk Lampu Mobil Otomatis Berbasis Arduino Uno,” RESISTOR (elektRonika kEndali telekomunikaSI tenaga liSTrik kOmputeR), vol. 1, no. 2, 2018.

[33] B. Budiyanto and F. Fadliondi, "The Improvement of Solar Cell Output Power Using Cooling and Reflection from Mirror," International Journal of Power Electronics and Drive Systems, vol. 8, no. 3, p. 1320, 2017.

[34] R. Samsinar, N. Purnomo, and D. Almanda, "Studi Kelayakan Core Iron Stator Dengan Metode Loop/ELCID Test," RESISTOR (elektRonika kEndali telekomunikaSI tenaga liSTrik kOmputeR), vol. 1, no. 2, pp. 103-116, 2018.

[35] C. S. Fillion, A. M. Burry, and V. Kozitsky, Methods and systems for character segmentation in automated license plate recognition applications. Google Patents, 2015.
[36] H. Priyanto, Pengolahan CItra Digital Teori dan Aplikasi Nyata. Bandung: Informatika, 2017. 